\title{
Zgłaszanie kandydatów w wyborach samorządowych na poziomie gminy
}

\author{
Piotr Uziębło \\ Dr hab. prof. UG, Uniwersytet Gdański, Wydział Prawa i Administracji, \\ Katedra Prawa Konstytucyjnego i Instytucji Politycznych \\ http://dx.doi.org/10.18778/8088-114-3.05
}

Problematyka zgłaszania kandydatów w wyborach, w tym również wyborach organów gminy, stanowi istotny element przesądzający o respektowaniu zasady wolnych wyborów we współczesnym państwie. Ma to również istotny związek z szeroko rozumianymi zasadami powszechności i równości wyborów. Analizując tę problematykę z perspektywy powyższych zasad, skoncentrować się trzeba przede wszystkim na ocenie, czy możliwości zgłaszania kandydatów pozwalają praktycznie każdemu na kandydowanie w wyborach do organów najniższego szczebla samorządu, a także na tym, czy obowiązujące regulacje nie powodują powstania nierówności pomiędzy podmiotami uczestniczącymi w wyborach oraz nie wprowadzają barier, których realność pokonania jest możliwa tylko dla największych i najbogatszych ugrupowań politycznych. W niniejszym artykule skoncentruję się na ocenie obowiązujących rozwiązań kodeksu wyborczego pod kątem realizacji powyższych wartości, badając nie tylko sferę dogmatyczną, ale również, choć w ograniczonym zakresie, praktykę ustrojową związaną z pierwszym zastosowaniem rozwiązań kodeksowych w wyborach samorządowych z $2014 \mathrm{r}$.

Podobnie jak i w innych elekcjach w Polsce, ustawodawca zdecydował w kodeksie wyborczym ${ }^{1}$, że zgłaszanie kandydatów w wyborach do rady gminy (miasta) oraz wyborach wójta (burmistrza, prezydenta miasta) ma mieć charakter dwuetapowy. Pierwszym etapem jest rejestracja komitetu wyborczego, zaś drugim - zgłaszanie kandydatów przez tak utworzony komitet. Rozwiązanie to można uznać za nietypowe, dlatego że poza Polską podobne rozwiązania stosowane są w zasadzie marginalnie ${ }^{2}$. Jego

1 Ustawa z dnia 5 stycznia 2011 r. Kodeks wyborczy, Dz.U. Nr 21, poz. 112 z późn. zm., zwany dalej k.wyb. lub kodeksem.

2 Zob. J. Szymanek, Prawna regulacja komitetów wyborczych w kodeksie wyborczym, [w:] Kodeks wyborczy. Wstępna ocena, red. K. Skotnicki, Warszawa 2011, s. 72-73. 
ratio legis wynika ze zróżnicowania podmiotów uprawnionych do zgłaszania kandydatów, a tym samym tworzenia komitetów. Utworzone przez różne podmioty komitety stanowią byty prawne o zbliżonym charakterze, co może ułatwiać jednolite ich traktowanie w toku całego procesu wyborczego, w tym też na etapie prowadzenia kampanii wyborczej i jej finansowania ${ }^{3}$. W efekcie wymóg formalny dający prawo zgłaszania kandydatów wyłącznie komitetom wyborczym, stanowi istotną wartość ustrojową.

W wyborach gminnych prawo do utworzenia komitetu wyborczego przysługuje partiom politycznym, ich koalicjom, stowarzyszeniom i organizacjom społecznym oraz wyborcom. Tworzenie komitetów jest zróżnicowane i zależy od podmiotu, który je tworzy ${ }^{4}$, choć w każdym przypadku zawiadomienie właściwego organu o jego utworzeniu musi zostać dokonane najpóźniej do 70. dnia przed dniem wyborów, co stanowi termin zawity, a jego przekroczenie zamyka drogę do wystawienia kandydatów w wyborach.

Komitet wyborczy partii politycznej tworzy organ uprawniony do reprezentowania partii na zewnątrz, natomiast koalicyjny komitet wyborczy jest tworzony przez co najmniej dziesięć osób wskazanych przez organy partii tworzące koalicję. Do zawiadomienia należy też dołączyć informację o powołaniu pełnomocnika wyborczego i pełnomocnika finansowego komitetu, a także nazwę i adres siedziby komitetu. Ponadto również załącza się odpis lub - w przypadku komitetu koalicyjnego - odpisy z ewidencji partii politycznych oraz treść umowy koalicyjnej oraz dane osobowe członków komitetu, odpisy ze statutu lub statutów wskazujące organy uprawnione do reprezentowania partii, dane osobowe pełnomocników i informację o przyjęciu przez nich pełnomocnictwa.

Inaczej wygląda zgłoszenie komitetów organizacji i stowarzyszeń ${ }^{5}$. Nie do końca precyzyjne jest określenie podmiotów, które mogą tworzyć komitety wyborcze organizacji. Kodeks wyborczy w art. $84 \$ 4$ wspomina o stowarzyszeniach i organizacjach społecznych, nie precyzując jednak ani tego, czy chodzi tu wyłącznie o stowarzyszenia rejestrowe, czy również stowarzyszenia zwykłe, ani tego czym jest organizacja społeczna, co jest szczególnie istotne $\mathrm{z}$ racji braku prawnego uregulowania funkcjonowania tego typu podmiotów. Odpowiedź na to pierwsze pytanie została udzielona w art. $402 \S 3$ pkt 2 , gdzie wyraźnie wskazano, że w przypadku

3 Ibidem, s. 76.

4 Jak słusznie zauważają M. Czakowska i P. Raźny nie wpływa to na realizację zasady równych szans wyborczych, zob. M. Czakowska, P. Raźny, Konstrukcja prawna komitetu wyborczego w kontekście zasady równych szans wyborczych, „Studia BAS” 2011, nr 3, s. 83.

5 Zgodzić się trzeba z J. Szymankiem, że możliwość tworzenia takich komitetów w wyborach lokalnych i regionalnych jest zasadna, realizując tym samym zasadę samorządności, zob. J. Szymanek, op. cit., s. 101-102. 
komitetów wyborczych tworzonych przez stowarzyszenia zwykłe, powinny one załączyć oświadczenie organu nadzorującego, że wpłynęła do niego informacja o założeniu stowarzyszenia zwykłego. Nie ma więc wątpliwości, że takie stowarzyszenia mogą również tworzyć komitety wyborcze. Natomiast w odniesieniu do innych organizacji społecznych przyjąć trzeba, że mogą nimi być wyłącznie organizacje, które posiadają osobowość prawną, gdyż w przypadku innych podmiotów niż wspomniane stowarzyszenie zwykłe, do zawiadomienia musi zostać dołączony uwierzytelniony odpis z Krajowego Rejestru Sądowego. Tym samym takimi organizacjami społecznymi innymi niż stowarzyszenia mogą być np. fundacje czy związki zawodowe ${ }^{6}$. Komitetem wyborczym takiego podmiotu jest jego organ uprawniony do reprezentowania organizacji na zewnątrz. Organ ten powołuje również pełnomocnika wyborczego oraz pełnomocnika finansowego. Zawiadomienie o utworzeniu komitetu powinno zawierać imiona, nazwiska, adresy zamieszkania i numery ewidencyjne PESEL takich pełnomocników, a także nazwę komitetu, adres jego siedziby oraz numer ewidencyjny, pod którym organizacja jest ujęta we właściwym rejestrze. Ponadto załącza się do niego, poza wskazanym powyżej odpisem z KRS lub oświadczeniem organu nadzorującego, oświadczenie obu pełnomocników o przyjęciu pełnomocnictwa i spełnieniu warunków stawianych pełnomocnikowi finansowemu, a także wyciąg ze statutu lub regulaminu działalności organizacji, który wskazuje organ upoważniony do jej reprezentowania.

Tworzenie komitetu wyborczego wyborców zależy od tego, na jakim obszarze komitet zamierza zgłaszać kandydatów. Jeśli zamierza on uczynić to $\mathrm{w}$ więcej niż jednym województwie, komitet powinien być utworzony przez co najmniej 15 osób posiadających czynne prawo wyborcze. $\mathrm{W}$ przeciwnym wypadku wystarczy, że utworzy go co najmniej 5 wyborców ${ }^{7}$. To samo kryterium różnicuje liczbę koniecznych do załączenia podpisów obywateli popierających utworzenie komitetu. $\mathrm{W}$ tym pierwszym przypadku niezbędne jest uzyskanie co najmniej 1000 podpisów wyborców, co jest wymogiem tożsamym z liczbą podpisów niezbędną dla zgłoszenia wniosku o wpis partii politycznej do ewidencji. Można więc stwierdzić, że stanowi to swoiste zrównanie wymogów stawianych komitetom partyjnym i komitetom wyborczym wyborców. Niestety w przypadku wyborów samorządowych można to uznać za nieuzasadnione

6 Jak zauważa B. Banaszak, dominującą rolę odgrywają tu komitety zakładane przez ochotnicze straże pożarne, zob. B. Banaszak, Kodeks wyborczy. Komentarz, Warszawa 2014, s. 600.

7 Regulacje przedkodeksowe wymagały co najmniej 5 wyborców dla utworzenia komitetu, bez względu na obszar, w którym komitet taki zamierzał wystawiać kandydatów, zob. art. 64f ustawy z dnia 16 lipca 1998 r. Ordynacja wyborcza do rad gmin, powiatów i sejmików województw (t.j. Dz.U. z 2003 r. Nr 159, poz. 1547 z późn. zm.). 
uprzywilejowanie komitetów organizacji, szczególnie tych, które są tworzone przez stowarzyszenia zwykłe, które owych podpisów gromadzić nie muszą, mimo że ich minimalna liczebność obejmuje trzech członków. W przypadku komitetów wyborczych wyborców, które swoją aktywność wyborczą zamierzają ograniczyć wyłącznie do terytorium jednego województwa poparcie dla ich utworzenia może być wyrażone przez podpisy co najmniej 20 wyborców.

Podobnie jak inne komitety wyborcze, również komitet wyborczy wyborców musi powołać pełnomocnika wyborczego i pełnomocnika finansowego, których dane osobowe wraz z nazwą komitetu ujmowane są w zawiadomieniu o utworzeniu komitetu. Do zawiadomienia załącza się też powyższe, wymagane prawem podpisy osób popierających utworzenia komitetu, a także oświadczenie o utworzeniu komitetu oraz oświadczenia pełnomocników o przyjęciu pełnomocnictwa, a w przypadku pełnomocnika finansowego również oświadczenie o spełnieniu przez niego stawianych prawem warunków do pełnienia takiej funkcji.

Warto dodać, że w przypadku, gdy komitet wyborczy wyborców zamierza zgłaszać jedynie kandydatów na radnych w gminie niebędącej miastem na prawach powiatu nie powołuje on odrębnego pełnomocnika finansowego, lecz jego obowiązki pełni pełnomocnik wyborczy. Komitet taki nie musi również zbierać podpisów wyborców popierających utworzenie komitetu. Wyłączenie to nie dotyczy sytuacji, w której komitet taki oprócz kandydatów na radnych zamierza zgłosić również kandydatów na wójta (burmistrza, prezydenta miasta), gdyż wyjątek ten musi być rozumiany wąsko, zgodnie z dokonaną wykładnią językową. Gdyby bowiem ustawodawca chciał ów wyjątek rozszerzyć również na wybory organu wykonawczego, powinno to jednoznacznie wynikać z treści kodeksu. Niestety w praktyce ustrojowej zdarzały się przypadki, w których komisje wyborcze rejestrowały kandydatów w wyborach organu wykonawczego gminy, zgłaszanych przez komitety nieposiadające pełnomocnika finansowego, i było to legitymizowane rozstrzygnięciami sądów, co w mojej ocenie trzeba ocenić negatywnie ${ }^{8}$.

W przypadku spełniania wymogów formalnych zawiadomienia, Państwowa Komisja Wyborcza (PKW), względnie właściwy komisarz wyborczy, jeśli zgłoszenie ma dotyczyć komitetu wyborczego wyborców lub organizacji, który zamierza zgłaszać kandydatów wyłącznie na terenie jednego województwa ${ }^{9}$, wydaje, w ciągu 3 dni od jego doręczenia, posta-

8 Zob. postanowienie SO w Koszalinie z dnia 17 grudnia 2014 r., I Ns 323/14, niepubl.

9 Takie rozwiązanie ma ułatwić funkcjonowanie niewielkich komitetów lokalnych i zapewnić im szanse podejmowania aktywności w tej mierze możliwie blisko obszaru ich działania. 
nowienie o przyjęciu zawiadomienia ${ }^{10}$. W przeciwnym wypadku organ wzywa pełnomocnika komitetu do usunięcia wad w terminie 5 dni. Jeśli wady te nie zostaną usunięte $\mathrm{w}$ terminie, wydawane jest postanowienie o odmowie przyjęcia zawiadomienia, które wraz z uzasadnieniem jest niezwłocznie doręczane pełnomocnikowi wyborczemu ${ }^{11}$. Ten ostatni może w terminie 3 dni od jego doręczenia złożyć skargę do Sądu Najwyższego (w przypadku postanowienia PKW) albo do PKW (w przypadku postanowienia komisarza wyborczego). Organy te rozpatrują sprawę w terminie 3 dni od wpłynięcia skargi i jeśli uznają skargę za zasadną, powoduje to obowiązek przyjęcia zawiadomienia przez właściwy organ (art. 404 i 405 k.wyb.). Postanowienie SN albo PKW rozpatrującego skargę na postanowienie komisarza wyborczego ma charakter ostateczny i nie może być dalej zaskarżane. Rozstrzygnięcia komisarza wyborczego nie podlegają ocenie dokonanej przez niezawisły sąd, a tym samym dochodzi tu do naruszenia prawa podmiotowego, jakim jest niemożność zamykania drogi sądowej w sferze realizacji praw jednostki. Nie stało się dobrze, że pomimo licznych nowelizacji kodeksu wyborczego, ten przepis nie został zmodyfikowany.

Utworzenie komitetu wyborczego nie oznacza zgłoszenia kandydatów w wyborach samorządowych, lecz stanowi pierwszy krok do dokonania takich czynności. Kolejnym etapem staje się zgłaszanie list kandydatów w wyborach do rady gminy (miasta), a także związane z tym ewentualne zgłoszenia kandydata na wójta (burmistrza, prezydenta miasta). Jednak bez utworzenia komitetu wyborczego dalsze działania nie byłyby możliwe, gdyż właśnie komitety posiadają monopol w sferze przedstawiania list kandydatów. Co specyficzne, polski ustawodawca przyjął, że nawet zgłoszenie wyłącznie jednego kandydata do rady gminy odbywa się w formie zgłoszenia listy, choć w przypadku miast na prawach powiatu nie ma prawnej możliwości zgłaszania pojedynczych kandydatów, gdyż lista kandydatów w okręgu nie może zawierać mniej niż 5 kandydatów ${ }^{12}$. Nie ma tu znaczenia liczba mandatów do obsadzenia w takim okręgu, który w skrajnym wypadku może obejmować aż 10 mandatów.

10 Zob. postanowienie SN z dnia 23 października 2014 r., III SW 73/14, LEX nr 1537273.

11 Zgodnie ze stanowiskiem SN brak informacji umożliwiających identyfikację osoby popierającej utworzenie komitetu nie jest możliwy po upływie terminu do zawiadomienia o utworzeniu komitetu, zob. postanowienie SN z dnia 29 sierpnia 2011 r., III SW 8/11, OSNP 2012, nr 11-12, poz. 150.

12 Może to utrudnić zgłaszanie list przez mniejsze komitety, zachęcając je, podobnie jak w wyborach sejmowych, do umieszczania na listach przypadkowych kandydatów, zob. A. Żukowski, System wyborczy do Sejmu i Senatu RP, Warszawa 2004, s. 110. 
Zgłoszenie listy kandydatów w wyborach do rady gminy musi zawierać ustalone kodeksowo elementy. Zgodnie $z$ art. $426 \$ 1$ podaje się $w$ nim „nazwę komitetu wyborczego oraz dokładny adres jego siedziby, nazwę rady gminy oraz numer okręgu wyborczego, do którego dokonuje się zgłoszenia oraz nazwiska i imiona ${ }^{13}$, wiek oraz miejsce zamieszkania kan-

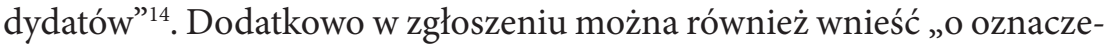
nie kandydatury nazwą lub skrótem nazwy partii politycznej lub organizacji popierającej kandydata" (art. $426 \S 6)^{15}$, przy czym fakt poparcia takiej kandydatury powinien zostać pisemnie potwierdzony przez właściwy statutowo organ partii lub organizacji. Załącznikami do zgłoszenia winny również być: dokument potwierdzający przyjęcie zawiadomienia o utworzeniu komitetu oraz pisemne oświadczenia kandydatów o wyrażeniu zgody na kandydowanie oraz o posiadaniu prawa wybieralności do danej rady, zawierające imię kandydata, jego nazwisko, nazwisko rodowe, imiona rodziców, datę i miejsce urodzenia, obywatelstwo oraz numer ewidencyjny PESEL, a także wskazanie jego przynależności do partii politycznej ${ }^{16}$. Wszystko to powinno zostać opatrzone datą złożenia oświadczenia i własnoręcznym podpisem kandydata. W przypadku kandydatów będących obywatelami polskimi, a urodzonymi przed 1 sierpnia $1972 \mathrm{r}$. konieczne jest też załączenie oświadczenia lustracyjnego.

Jak już wspomniano, w miastach na prawach powiatu każda lista powinna zawierać co najmniej 5 kandydatów, nie więcej jednak niż dwukrotność liczby mandatów obsadzanych w okręgu. W wyborach tych został przyjęty system kwot płci, co oznacza, że liczba kandydatów jednej z płci nie może być mniejsza niż 35\% liczby wszystkich kandydatów na liście. Kwoty te są przyjmowane osobno dla każdej listy okręgowej zgłaszanej przez komitet. Niespełnienie powyższych warunków, po bezskutecznym upływie terminu na naprawienie takich wad, skutkuje odmową rejestracji listy kandydatów. Kwoty płci nie obowiązują natomiast w pozostałych gminach, co jest w dużej mierze efektem występowania tam jednoman-

13 Powinny być to wszystkie imiona wskazane w dowodzie osobistym, zob. B. Dauter, Uwagi do art. 426, [w:] K.W. Czaplicki, B. Dauter, S. J. Jaworski, A. Kisielewicz, F. Rymarz, Kodeks wyborczy. Komentarz, Warszawa 2014, SIP LEX.

14 Kolejność kandydatów na liście ustala komitet.

15 Nazwa taka nie może jednak być więcej niż jedną nazwą lub jednym skrótem nazwy składającymi się z nie więcej niż 45 znaków drukarskich, wliczając w to spacje.

16 Zgodnie z art. 426 § 3. „w przypadku zgłoszenia kandydatury obywatela Unii Europejskiej niebędącego obywatelem polskim do pisemnej zgody kandydata na kandydowanie dołącza się również: oświadczenie kandydata określające ostatni adres zamieszkania w państwie członkowskim Unii Europejskiej jego pochodzenia; oświadczenie kandydata, że nie został pozbawiony prawa do kandydowania w państwie członkowskim Unii Europejskiej jego pochodzenia oraz oświadczenie kandydata, że nie pełni on urzędu, który objęty jest zakazem łączenia funkcji”. 
datowych okręgów wyborczych ${ }^{17}$. W tych okręgach komitet może zgłosić bowiem listę kandydatów obejmującą wyłącznie jedną osobę w każdym okręgu. Nie zdecydowano się na wprowadzenie rozwiązania, które powodowałoby konieczność zachowania minimalnej liczby kandydatów jednej płci wśród wszystkich kandydatów wystawianych przez jeden komitet w skali gminy. Regulacja taka byłaby stosunkowo łatwa do obejścia, chociażby poprzez uczestnictwo w wyborach części takich kandydatów z indywidualnych komitetów wyborczych o "satelickim” charakterze, a wspieranych przez ów komitet „główny”.

Zgłoszenie list kandydatów wymaga ich poparcia przez wyborców zamieszkałych na terenie gminy i ujętych w prowadzonym przez nią rejestrze wyborców. W przypadku miast na prawach powiatów każda lista okręgowa musi uzyskać pisemne poparcie co najmniej 150 wyborców ${ }^{18}$, w pozostałych gminach -25 wyborców, co jest liczbą niewielką, nieblokującą dostępu do zgłaszania kandydatów przez mniejsze komitety. Można mieć zastrzeżenia, że ustawodawca nie przyjął zasady, że poparcie takie może być udzielane wyłącznie przez wyborców zamieszkałych w okręgu, w którym owa lista ma być zgłaszana. W mojej ocenie jest to poważny błąd, gdyż w skrajnym przypadku żaden z wyborców zamieszkałych w danym okręgu nie wesprze listy, która zostanie później zarejestrowana. Wyborca może udzielać poparcia dowolnej liczbie list, zarówno zgłaszanych przez jeden komitet, jak również różne komitety i - co szczególnie istotne - poparcie takie nie może być w żadnym wypadku wycofane. Poparcie wyrażane jest poprzez umieszczenie swojego własnoręcznego podpisu obok czytelnie wypisanego swojego nazwiska i imienia, adresu zamieszkania oraz numeru ewidencyjnego PESEL ${ }^{19}$. Trzeba podkreślić,

17 Podobnie M. Chmaj, Parytet ptci w kodeksie wyborczym, [w:] Kodeks wyborczy. Wstępna ocena, red. K. Skotnicki, Warszawa 2011, s. 205.

18 Zgodzić się trzeba ze zdaniem B. Banaszaka, że niższa liczba podpisów w wyborach do rad miast na prawach powiatów niż do rady powiatu nie znajduje uzasadnienia, zob. B. Banaszak, op. cit., s. 627-628.

19 Kodeks nie wskazuje jednoznacznie, co oznacza pojęcie adresu zamieszkania. Stąd też mogą pojawiać się wątpliwości, czy drobne braki, np. kodu pocztowego czy numeru mieszkania powinny stanowić o nieskuteczności udzielonego poparcia. PKW uznaje, że braki takie skutkują uznaniem poparcia za wadliwe. Dopuszczalne jest natomiast posłużenie się przez wyborcę nie oficjalną nazwą miejscowości, lecz „powszechnie używanym i jednoznacznie rozumianym skrótem tej nazwy”, Informacja Państwowej Komisji Wyborczej z dnia 30 czerwca 2014 r. o zasadach i sposobie zgłaszania list kandydatów na radnych w wyborach do rad gmin (rad miejskich, rad miast) w gminach niebędących miastami na prawach powiatu, które będą zarządzone na dzień 16 listopada 2014 r., ZPOW-703-114/14, http://pkw.gov.pl/zglaszanie-kandydatow-samorzad-2014/ informacja-panstwowej-komisji-wyborczej-z-dnia-30-czerwca-2014-r-o-zasadach-isposobie-zglaszania-list-kandydatow-na-radnych-w-wyborach-do-rad-gmin-rad-miejskich-rad-miast-w-gminach-niebedacych-miastami-na-prawach-powiatu-ktore-bedazarzadzone-na-dzien-16.html (dostęp 19.07.2015). 
że wszystkie te dane - poza podpisem - nie muszą być wypełnione przez samego wyborcę ${ }^{20}$.

Kodeks określa również wymogi stawiane arkuszom do zbierania podpisów, zwanymi wykazami podpisów. Winny one zawierać na każdej ze stron wykazu „nazwę komitetu wyborczego zgłaszającego listę, numer okręgu wyborczego, w którym lista jest zgłaszana, nazwiska i imiona zgłaszanych kandydatów oraz adnotację: »Udzielam poparcia liście kandydatów zgłaszanej przez ... (nazwa komitetu wyborczego) w okręgu wyborczym nr ... (numer okręgu) w wyborach do Rady ... (nazwa rady) zarządzonych na ... (dzień, miesiąc, rok) «” (art. $427 \$ 4)$. Nie ma natomiast żadnych wymogów dotyczących trwałego zszycia ze sobą poszczególnych stron wykazu, co pozwala na zbieranie podpisów przez różne osoby, a dopiero potem ich zbiorcze złożenie ${ }^{21}$.

Procedura zgłaszania list kandydatów do właściwego organu wyborczego, jakim jest gminna (miejska) komisja wyborcza, nie jest specjalnie skomplikowana. Zgłoszenie listy wyborczej może być dokonane przez pełnomocnika wyborczego komitetu lub osobę przez niego upoważnioną. Upoważnienie takie musi zostać dokonane w formie pisemnej, co pośrednio wynika z brzmienia art. $428 \$ 3$. Zgodnie z nim do zgłoszenia załącza się również upoważnienie wydane przez pełnomocnika wyborczego. Trudno sobie wyobrazić jego załączenie w innej formie, np. formie elektronicznej czy zapisu dźwiękowego, chociażby z racji trudności weryfikacji, czy upoważnienie takie rzeczywiście zostało wystawione przez pełnomocnika. Potwierdzenie dokonania zgłoszenia dokonywane jest przez komisję, która na zgłoszeniu umieszcza datę i godzinę oraz liczbę porządkową jego wpływu.

Zgłoszenie takie musi zostać dokonane najpóźniej w 40. dniu przed dniem wyborów do godziny 24.00. Powinno ono spełniać wszystkie wcześniej wskazane wymogi, a także zawierać „dokument, wydany przez komitet wyborczy, stwierdzający ustanowienie pełnomocnika wyborczego, z podaniem jego nazwiska i imienia oraz dokładnego adresu zamieszkania i numeru ewidencyjnego PESEL” (art. 428 \$ 2). W wypadku niespełnienia owych wymogów komisja wyborcza po weryfikacji zgłoszenia list kandydatów wzywa osobę zgłaszającą listę do uzupełnienia braków

20 Por. S. Kowalski, Karnoprawna ochrona wykazu podpisów wyborców w wyborach samorzadowych, „Prokuratura i Prawo” 2014, nr 9, s. 76.

21 PKW wskazuje, że wykaz ten może być również drukowany dwustronnie, a także zawierać inne niż wskazane w k.wyb. informacje, o ile nie wprowadzają one wyborców w błąd, zob. Wyjaśnienia Państwowej Komisji Wyborczej z dnia 30 września 2014 r. dotyczące sporządzania wykazów podpisów poparcia dla zgłoszenia listy, ZPOW-703-712/14, http://pkw.gov.pl/wyjasnienia-informacje-i-pisma-okolne-samorzad-2014/wyjasnienia-panstwowej-komisji-wyborczej-z-dnia-30-wrzesnia-2014-r-wsprawie-wykazow-podpisow-poparcia-dla-zgloszenia-listy.html (dostęp 19.07.2015). 
$\mathrm{w}$ terminie 3 dni. Wyjątkiem jest sytuacja, gdy brakiem takim jest niewłaściwa liczba podpisów osób popierających listę. W takim przypadku dostarczenie dodatkowych podpisów jest możliwe wyłącznie wtedy, gdy nie upłynął jeszcze termin na zgłaszanie list kandydatów. Dlatego też dokonanie zgłoszenia tuż przed upływem 40-dniowego terminu niesie w sobie ryzyko, że jeśli część podpisów będzie złożona w sposób niewłaściwy, to komitet wyborczy zamknie sobie drogę do wystawienia kandydatów w takim okręgu ${ }^{22}$.

Nieuzupełnienie braków w terminie, uzupełnienie ich w sposób niewłaściwy lub też wystąpienie braków niesanowalnych ${ }^{23}$ zobowiązuje gminną komisję wyborczą do odmowy rejestracji zgłoszenia w całości lub też co do poszczególnych kandydatów. W tym ostatnim przypadku, występującym wyłącznie w miastach na prawach powiatów, zarejestrowanie listy jest możliwe, o ile pozostanie na niej minimalna, wymagana kodeksem liczba kandydatów. Rozstrzygnięcie w sprawie rejestracji listy wyborczej albo jej odmowy dokonywane jest w formie uchwały, która wraz z uzasadnieniem niezwłocznie jest doręczana osobie zgłaszającej listę. Może ona, w terminie 3 dni od daty jej doręczenia, wnieść odwołanie do komisarza wyborczego, który rozpatruje je w terminie 3 dni i wydaje postanowienie w sprawie odwołania. Postanowienie to nie jest ostateczne, gdyż jeśli uznaje ono odwołanie za nieuzasadnione „osobie zgłaszającej listę przysługuje prawo wniesienia skargi do PKW w terminie 3 dni od daty doręczenia postanowienia komisarza wyborczego. PKW rozpatruje skargę i wydaje postanowienie $\mathrm{w}$ terminie 3 dni. Od jej postanowienia nie przysługuje środek prawny" (art. $432 \$ 2$ ). W konsekwencji, pomimo wystąpienia aż trójinstancyjności postępowania i w tym przypadku nie ma możliwości sądowej weryfikacji rozstrzygnięcia organów wyborczych, czego nie zmienia fakt, że organy odwoławcze mają charakter sędziowski ${ }^{24}$.

Brak wad w zgłoszeniu, względnie korzystne dla komitetu postanowienie komisarza wyborczego lub PKW, skutkuje obowiązkiem niezwłocznego zarejestrowania zgłoszonych list kandydatów w okręgu przez gminną (miejską) komisję wyborczą, która sporządza jednocześnie protokół rejestracji, który po jednym egzemplarzu doręczany jest osobie zgłaszającej listę oraz właściwemu komisarzowi wyborczemu. Ponadto rejestracja listy rodzi zobowiązanie komisji do niezwłocznego przekazania oświadczeń lustracyjnych kandydatów do oddziałowego biura lustracyjnego

22 Por. M. Bąkiewicz, System wyborczy do samorządu terytorialnego w Polsce na tle europejskim, Toruń 2008, s. 105.

23 Takim brakiem jest np. zgłoszenie listy kandydatów obejmującej mniej niż wymaganych ustawowo pięć nazwisk, zob. B. Dauter, Uwagi do art. 430, [w:] K.W. Czaplicki, B. Dauter, S. J. Jaworski, A. Kisielewicz, F. Rymarz, Kodeks wyborczy. Komentarz, Warszawa 2014, SIP LEX.

24 B. Banaszak, op. cit., s. 633. 
Instytutu Pamięci Narodowej - Komisji Ścigania Zbrodni przeciwko Narodowi Polskiemu właściwego ze względu na miejsce zamieszkania poszczególnych kandydatów.

Pewne odmienności dotyczą rejestracji kandydatów na wójta (burmistrza, prezydenta miasta). Trzeba zwrócić uwagę, że nie ma możliwości zgłoszenia takiego kandydata bez rejestracji list kandydatów do rady gminy. Teoretycznie ma to sprzyjać posiadaniu przez organ wykonawczy popierających go radnych, jednak w praktyce może prowadzić do zablokowania zgłaszania kandydatów rzeczywiście niezależnych, jak również do sztucznego zapełniania kandydatami list w wyborach do rady gminy, tylko po to, aby umożliwić komuś kandydowanie na wójta (burmistrza, prezydenta miasta). Prawo zgłaszania kandydatów na wójta (burmistrza, prezydenta miasta) ma bowiem wyłącznie taki komitet wyborczy, który zarejestrował listy kandydatów na radnych w co najmniej połowie okręgów wyborczych w danej gminie. Dodatkowo również w każdym $\mathrm{z}$ tych okręgów liczba zarejestrowanych przez ten komitet kandydatów na radnych nie może być mniejsza niż liczba radnych wybieranych w tym okrę$\mathrm{gu}^{25}$. Słusznie odbierane jest to przez doktrynę jako uprzywilejowanie dużych stronnictw politycznych ${ }^{26}$.

Inaczej wygląda sytuacja w wyborach przedterminowych niepowiązanych $\mathrm{z}$ wyborami organu stanowiącego. Wybory takie nie wiążą kandydata $\mathrm{z}$ komitetem wyborczym wystawiającym kandydatów do rady gminy (miasta). Dlatego też kandydatura wójta (burmistrza, prezydenta miasta) musi zostać pisemnie poparta przez wyborców, których liczba zależy od liczby mieszkańców gminy. I tak w gminach do 5 tys. mieszkańców poparcie musi być wyrażone przez co najmniej 150 wyborców, w gminach do 10 tys. mieszkańców - 300 wyborców, w gminach do 20 tys. mieszkańców - 600 wyborców, w gminach do 50 tys. mieszkańców - 1500 wyborców, w gminach do 100 tys. mieszkańców - 2 tys. wyborców, zaś w gminach powyżej 100 tys. mieszkańców - 3 tys. wyborców. Podzielając stanowisko ustawodawcy, że liczba podpisów powinna się zwiększać wraz z liczbą mieszkańców gminy, mam jednak obawy, że przyjęcie rozwiązania szczeblowanego, sztywno zakreślającego ramy liczbowe, nie jest najszczęśliwsze. Stoję na stanowisku, że lepsze byłoby wprowadzenie procentowej liczby podpisów, najlepiej liczonej nie od mieszkańców, lecz wyborców, dodatkowo z pojawiającą się degresją, która zmniejszałaby wzrost wymaganej liczby podpisów wraz ze zwiększaniem się liczby wy-

25 W praktyce może to powodować problemy mniejszych komitetów, które nie są świadome konieczności łącznego spełnienia obu warunków, czego przykładem jest przypadek komitetu Gdynia dla Ludzi w wyborach z 2014 r.

26 M. Mączyński, Uniformizacja wyborów samorzq̨owych w gminie? Dylematy ustrojowe i polityczne, [w:] Wybory i referenda lokalne. Aspekty prawne i politologiczne, red. M. Stec i K. Małysa-Sulińska, Warszawa 2010, s. 33. 
borców. Obecne unormowanie, szczególnie w gminach niewiele ponad dwudziestotysięcznych może prowadzić do konieczności uzyskania poparcia dla kandydatury na poziomie prawie $10 \%$ wyborców, co w mojej ocenie jest rozwiązaniem zbyt restrykcyjnym ${ }^{27}$.

Wymogi formalne stawiane zgłoszeniu są w zasadzie tożsame z wymogami stawianymi zgłaszaniu kandydatów na radnych ${ }^{28}$. Jeśli zgłoszenie spełnia powyższe warunki, gminna (miejska) komisja wyborcza rejestruje kandydata niezwłocznie po weryfikacji zgłoszenia, jednocześnie doręczając po jednym egzemplarzu protokołu rejestracji osobie zgłaszającej kandydata i komisarzowi wyborczemu. W przypadku odmowy zarejestrowania kandydata procedura odwoławcza jest analogiczna jak w przypadku odmowy rejestracji list w wyborach do organu stanowiącego gminy, czyli od powyższej uchwały przysługuje odwołanie do komisarza wyborczego, a od jego postanowienia - ewentualnie również do PKW.

Podsumowując, kodeks nie stanowi istotnej, jakościowej zmiany w sferze zgłaszania kandydatów w wyborach organów: stanowiącego i wykonawczego w gminie. Nie zaszły bowiem istotne zmiany z punktu widzenia kształtu regulacji tej procedury. Można uznać, że cała procedura zgłaszania kandydatów, zarówno w fazie tworzenia komitetów wyborczych, jak również rejestracji list wyborczych, nie narusza zasad równości szans wyborczych, jak również powszechności prawa wyborczego $\mathrm{w}$ aspekcie realizacji biernego prawa wyborczego ${ }^{29}$. Niemniej jednak niektóre rozwiązania nie są precyzyjne i powodują rozbieżności w praktyce postępowania organów wyborczych, czego najlepszym przykładem była możliwość zgłaszania kandydatów na wójta (burmistrza) przez komitety, które nie posiadały wyodrębnionego pełnomocnika finansowego. Podobnie refleksji wymaga brak możliwości skorzystania z drogi sądowej w procedurze przyjmowania zawiadomienia o utworzeniu komitetu przez komisarza wyborczego oraz w toku rejestracji list kandydatów.

27 Por. G. Kryszeń, Problematyka zgłaszania list kandydatów w świetle kodeksu wyborczego, [w:] Kodeks wyborczy. Wstępna ocena, red. K. Skotnicki, Warszawa 2011, s. 183.

28 Różnicą jest jedynie obowiązek podania wykształcenia kandydata (art. 479 $\S 1$ k.wyb.).

29 Świadczy o tym fakt, że w wyborach samorządowych utworzono 12582 komitety, z czego aż 12133 komitety wyborcze wyborców, http://wybory2014.pkw.gov.pl/ pl/komitety/ (dostęp 23.07.2015). 


\section{Bibliografia}

Banaszak B., Kodeks wyborczy. Komentarz, Warszawa 2014.

Bąkiewicz M., System wyborczy do samorzadu terytorialnego w Polsce na tle europejskim, Toruń 2008.

Chmaj M., Parytet ptci w kodeksie wyborczym, [w:] Kodeks wyborczy. Wstępna ocena, red. K. Skotnicki, Warszawa 2011.

Czakowska M., Raźny P., Konstrukcja prawna komitetu wyborczego w kontekście zasady równych szans wyborczych, „Studia BAS” 2011, nr 3.

Dauter B., Uwagi do art. 426, [w:] Czaplicki K.W., Dauter B., Jaworski S.J., Kisielewicz A., Rymarz F., Kodeks wyborczy. Komentarz, Warszawa 2014.

Dauter B., Uwagi do art. 430, [w:] Czaplicki K.W., Dauter B., Jaworski S.J., Kisielewicz A., Rymarz F., Kodeks wyborczy. Komentarz, Warszawa 2014.
Kowalski S., Karnoprawna ochrona wykazu podpisów wyborców w wyborach samorządowych, „Prokuratura i Prawo" 2014, nr 9.

Kryszeń G., Problematyka zgłaszania list kandydatów w świetle kodeksu wyborczego, [w:] Kodeks wyborczy. Wstępna ocena, red. K. Skotnicki, Warszawa 2011.

Mączyński M., Uniformizacja wyborów samorzadowych w gminie? Dylematy ustrojowe i polityczne, [w:] Wybory i referenda lokalne. Aspekty prawne i politologiczne, red. M. Stec i K. Matysa-Sulińska, Warszawa 2010.

Szymanek J., Prawna regulacja komitetów wyborczych w kodeksie wyborczym, [w:] Kodeks wyborczy. Wstępna ocena, red. K. Skotnicki, Warszawa 2011.

Żukowski A., System wyborczy do Sejmu i Senatu RP, Warszawa 2004. 